\title{
Podstawy teoretyczne stabilizacyjnej roli narzędzi fiskalnych w gospodarce rynkowej
}

\section{THEORETICAL BASIS OF THE STABILIZING ROLE OF FISCAL INSTRUMENTS IN A MARKET ECONOMY}

\footnotetext{
$W$ wysoko rozwiniętych gospodarkach rynkowych sq podejmowane za pomoca narzędzi fiskalnych lub/i pieniężnych działania stabilizacyjne, których celem jest m.in. wplywanie na morfologie cykli koniunkturalnych, na równowage na rynku pracy $i$ dażenie do utrzymywania stabilnej wartości pieniqdza. Celem pracy jest zbadanie hipotetycznego wptywu dyskrecjonalnych jak $i$ automatycznych narzędzi polityki fiskalnej na stabilizacje sfery realnej jak $i$ nominalnej zamkniętej gospodarki rynkowej.

Praca ma charakter rozważań hipotetycznych, a na jej poczqtku zostanq sformułowane cele stabilizacji makroekonomicznej $i$ możliwości ich realizacji. $W$ dalszej cześsi zostana przedstawione narzędzia fiskalne dyskrecjonalne $i$ działajace automatycznie $i$ charakter ich wptywu na osiaganie sformułowanych wcześniej celów.

Instrumenty fiskalne moga $i$ powinny być stosowane $w$ dzialaniach stabilizacyjnych, a szczególnie ważne powinny być narzędzia działajace automatycznie.
}

Słowa kluczowe: stabilizacja makroekonomiczna, narzędzia fiskalne dyskrecjonalne i automatyczne, wahania koniunkturalne, bezrobocie, inflacja.

JEL Codes: E62,E32.

\section{Wstęp}

W realizowanych $\mathrm{w}$ gospodarkach rynkowych działaniach stabilizacyjnych są wykorzystywane obok narzędzi pieniężnych także instrumenty fiskalne. Rola dochodów i wydatków publicznych jest istotna, gdyż w sposób bezpośredni lub pośredni wpływają one na kształtowanie popytu rynkowego, zarówno na dobra konsumpcyjne jak i na środki inwestycyjne, a także na zmiany podaży tych produktów.

Celem pracy jest określenie hipotetycznego wpływu dyskrecjonalnych jak i działających automatycznie narzędzi polityki fiskalnej na stabilizację sfery realnej jak i nominalnej gospodarki rynkowej. Wewnętrzna stabilizacja makroekonomiczna danego systemu będzie obejmowała zarówno politykę antycykliczną, tj. wpływanie na cechy morfologiczne cykli koniunkturalnych, politykę pełnego zatrudnienia, której zamiarem jest osiągnięcie równowagi na rynku siły roboczej oraz politykę antyinflacyjną, dążącą do utrzymania stabilnej wartości pieniądza.

Praca ma charakter teoretyczny, a w pierwszej części zostaną sformułowane cele polityki stabilizacji makroekonomicznej, następnie podejmowane za pomocą narzędzi 
dyskrecjonalnych i automatycznych działania fiskalne w sferze realnej i nominalnej w zamkniętym systemie rynkowym.

\section{Polityka stabilizacji makroekonomicznej oraz znaczenie dyskrecjonalnych i automatycznych narzędzi fiskalnych w procesie stabilizacji wewnętrznej systemu rynkowego}

$\mathrm{W}$ działaniach stabilizacyjnych, prowadzonych $\mathrm{w}$ gospodarkach rynkowych, często są wykorzystywane działające dyskrecjonalnie lub automatycznie narzędzia fiskalne. Poniżej zostaną przedstawione, przyjmowane w okresie krótkim i średnim, cele wewnętrznej stabilizacji makroekonomicznej wśród których w ekonomii keynesowskiej najważniejszą rolę odgrywają, tworząc tzw. magiczny wielokąt, dążenie do osiagania szybkiego i pozbawionego wahań koniunkturalnych wzrostu gospodarczego, utrzymania równowagi na rynku pracy i zapewnienie stabilnej wartości pieniądza. Osiaganie tych celów będzie analizowane poprzez pryzmat oddziałania dyskrecjonalnych i automatycznych narzędzi fiskalnych.

\section{Cele stabilizacji makroekonomicznej w gospodarkach rynkowych}

Jednym z ważniejszych zadań, które współcześnie są podejmowane przez organy państwa w okresie krótkim i średnim jest polityka stabilizacji makroekonomicznej. Obejmuje ona ogół przedsięwzięć, których zamiarem jest dążenie do tworzenia warunków i utrzymywania równowagi ogólnogospodarczej, tj. przeciwdziałanie lub łagodzenie skutków występowania krótko- i średniookresowych zmian aktywności gospodarczej, zarówno sfery realnej jak i nominalnej. Głównym jej zadaniem nie jest zapobieganie występowaniu jakichkolwiek fluktuacji poszczególnych elementów gospodarki, ale czuwanie nad tym, aby oscylacje te się znosiły, a nie wzajemnie wzmacniały (Despres i in., 1975).

Celem polityki stabilizacji jest osiaganie równowagi makroekonomicznej. W tym przypadku chodzi nie tylko o zapewnienie ogólnej równowagi między efektywnym popytem i globalną podażą na rynku dóbr i usług, $\mathrm{z}$ zachowaniem równowag cząstkowych, ale i o przeciwdziałanie skutkom kumulacyjnych procesów w gospodarce, zarówno, jeżeli chodzi o utrzymanie wysokiej stopy wzrostu gospodarczego, jak i o zapobieganie występowaniu zbyt głębokich załamań, a także o oddziałanie na dynamikę wzrostu i proporcje podaży czynników produkcji (Barczyk, 2004).

Tak sformułowany cel ogólny jest $\mathrm{w}$ stosunkowo niskim stopniu przydatny w prowadzonej polityce gospodarczej. Podejmując próbę zbliżenia go do warunków rzeczywistości gospodarczej, można stwierdzić, że zadaniem polityki stabilizacji jest dążenie do tego, aby $\mathrm{w}$ warunkach systemu rynkowego osiagnąć wysoki i zrównoważony wzrost gospodarczy, wysoki poziom zatrudnienia, stabilną wartość pieniądza, a w warunkach gospodarki otwartej równowage $\mathrm{w}$ kontaktach z zagranicą. $\mathrm{W}$ ten sposób powstał czworokąt celów stabilizacyjnych, który często jest uzupełniany o dodatkowe elementy. Wśród nich można wyróżnić sprawiedliwy podział dochodu narodowego i kapitału, równowagę ekologiczną (Mussel, Pätzold, 2008) czy też zrównoważony wynik budżetu państwa (Kołodko, 1993).

Analizując powyższe cele stabilizacji, można stwierdzić, że osiąganie wysokiej dynamiki wzrostu gospodarczego jest możliwe m.in. w warunkach ograniczania 
amplitudy wahań koniunkturalnych, w sytuacji pełnego zatrudnienia i niskiej inflacji. Stąd też w ekonomii stworzonej przez J.M. Keynesa uważa się, że w gospodarce zamkniętej cele te tworzą magiczny trójkąt, a szczególną rolę pełni wysoki poziom zatrudnienia oraz stabilizacja wartości pieniądza. Realizacja tych zamiarów często gwarantuje osiaganie równowagi ogólnogospodarczej (Cassel, Thieme, 1997).

Wysoki poziom zatrudnienia jest związany z szybkim wzrostem gospodarczym, który może być wynikiem zwiększenia stopnia wykorzystania istniejących zdolności wytwórczych (efekt zdolności) lub też może być spowodowany zwiększeniem zdolności produkcyjnych wskutek działalności inwestycyjnej - efekt mocy (Pätzold, 1991). Poziom zatrudnienia jest często interpretowany w szerokim lub wąskim znaczeniu. W pierwszym przypadku oznacza on pełne wykorzystanie wszystkich czynników produkcji, a przede wszystkim pracy i kapitału. W wąskim znaczeniu pojęcie to jest rozumiane jedynie jako pełne zatrudnienie pracy. W tej sytuacji przyjmuje się, że wszyscy pracownicy, którzy poszukuja pracy, przy istniejących stawkach płac, mogą ja znaleźć w pełnym wymiarze bez nadmiernej zwłoki. W literaturze najcześciej twierdzi się, że pełne zatrudnienie siły roboczej występuje przy stopie bezrobocia naturalnego, której wartość jest zawarta w przedziale 1.5-4.0\%.

Stabilizacja wartości pieniądza, która najczęściej przejawia się w stałości ogólnego poziomu cen, ma istotne znaczenie dla osiagania równowagi ogólnogospodarczej. W tym przypadku przyjmuje się, że występuje ona wówczas, gdy wartość koszyka podstawowych dóbr i usług konsumpcyjnych nie ulega zmianie, a więc siła nabywcza pieniądza jest stała. Osiąganie tego celu ma miejsce, gdy średnioroczny przyrost indeksu dynamiki cen podstawowych artykułów i usług konsumpcyjnych wynosi około 2-3\%.

Kolejny cel polityki stabilizacji dotyczy gospodarki otwartej, utrzymującej kontakty z zagranica. $\mathrm{W}$ tym przypadku chodzi o mało precyzyjny cel dotyczacy utrzymania równowagi danej gospodarki $\mathrm{w}$ jej relacjach ekonomicznych $\mathrm{z}$ zagranica. Najczęściej jest on rozumiany jako sytuacja, w której stosunki z zagranicą nie generują negatywnych konsekwencji dla danego systemu, a w szczególności nie powodują wzrostu ogólnego poziomu cen i liczby bezrobotnych. Tak interpretowane pojęcie równowagi staje się również warunkiem stabilizacji ogólnogospodarczej. Główne stosowane mierniki empiryczne, służące do pomiaru stopnia realizacji tego celu, to bilans handlowy lub płatniczy danego kraju.

$\mathrm{W}$ polityce stabilizacji niekiedy przyjmuje się, że jej celem jest również sprawiedliwy podział dochodu narodowego $i$ kapitału. Zamiar ten nie jest explicite formułowany, gdyż ma on charakter nie tylko ekonomiczny, ale i społeczno-polityczny czy moralno-etyczny, a ponadto bardzo trudno jest go skonkretyzować, tak by mógł on być przedmiotem analiz ilościowych. Stąd też w praktyce gospodarczej są przyjmowane różne wskaźniki, które odzwierciedlają stopień jego realizacji.

Formułowanie celu, jakim jest równowaga ekologiczna, rozumiana jako utrzymanie stanu i poprawa istniejącego środowiska naturalnego, wynika przede wszystkim z niesprawności mechanizmu kształtowania się cen, który często prowadzi do zakłóceń w otoczeniu przyrodniczym.

Utrzymanie równowagi $\mathrm{w}$ sferze budżetu jest najczęściej interpretowane jako dążenie do osiagnnięcia nadwyżki wydatków nad dochodami, która będzie gwarantowała kształtowanie długu publicznego na poziomie umożliwiającym jego bezinflacyjne finansowanie. 
Przedstawione cele polityki stabilizacji makroekonomicznej, łączą się i splatają z zamierzeniami polityki gospodarczej i tworzą one nie zawsze wewnętrznie spójny system. Często uważa się, że powstaje magiczny wielokąt celów, co oznacza, że są one pewną koncepcją teoretyczną, jednakże osiagnięcie wszystkich z nich jest bardzo często utrudnione, a czasami wręcz niemożliwe. Przedstawiona hierarchia celów polityki stabilizacji jest jedynie pewnym zabiegiem porządkującym te analizy $\mathrm{i}$ jest uwarunkowana nie tylko przez dominującą $\mathrm{w}$ danym kraju koncepcję teoretyczna, lecz także przez konkretne warunki, w jakich działa gospodarka.

Przedmiotem szczegółowych analiz, zawartych $\mathrm{w}$ dalszych rozważaniach będzie charakter stabilizacyjnego, oddziałania dyskrecjonalnych i automatycznych instrumentów polityki fiskalnej, zarówno na sferę realną gospodarki, tj. na zrównoważony wzrost gospodarczy oraz pełne zatrudnienie, jak i na sferę nominalną, charakteryzowaną przez procesy inflacyjne w gospodarce polskiej.

Stabilizacyjne oddziałanie dyskrecjonalnych i automatycznych narzędzi fiskalnych

W gospodarkach rynkowych, zgodnie z koncepcją J.M. Keynesa, występują wewnętrzne mechanizmy prowadzące do nierównowagi, a których konsekwencją są m.in. wahania koniunkturalne lub też inflacja.

Realizowana w tych warunkach polityka fiskalna polega na gromadzeniu dochodów publicznych (budżetowych) w taki sposób aby ich poziom i struktura były determinowane przez proces wydatkowania środków publicznych (Nasiłowski, 1996). Polityka ta polega na wykorzystaniu różnych instrumentów, których zadaniem jest (Owsiak, 2005):

- zaspokojenie popytu państwa na pieniądz;

- realizacja statutowych obowiązków państwa za pomocą zgromadzonych środków pieniężnych;

- realizacja pozafiskalnych celów przy wykorzystaniu instrumentów fiskalnych.

- Większość narzędzi polityki fiskalnej jest wykorzystywana w procesie stabilizacji makroekonomicznej jako:

- instrumenty dyskrecjonalne;

- automatyczne stabilizatory koniunktury.

Instrumenty dyskrecjonalne to podejmowane ad hoc świadome działania organów państwa, których celem jest przeciwdziałanie wszelkim dysproporcjom powstającym w systemie gospodarczym. Cel ten jest osiagany przede wszystkim poprzez oddziałanie na zmiany popytu globalnego i jego części składowych (Hansen, 1949). W działaniu tym przyjmuje się, że popyt ten jest bezpośrednio kształtowany przez dochody podatkowe lub przez wydatki państwa na zakup dóbr konsumpcyjnych lub środków inwestycyjnych.

Dyskrecjonalne narzędzia fiskalne występują zarówno po stronie dochodów jak i wydatków budżetowych. W sferze dochodów publicznych dominuje polityka podatkowa, która jest interpretowana jako świadome, kierowane na określoną sytuację lub proces oddziałanie państwa za pomocą instrumentów fiskalnych. W grupie narzędzi dyskrecjonalnych dominują podatki pośrednie od wartości dodanej oraz akcyza. Polityka, ta może polegać na zmianie stawek podatkowych lub/i podstawy opodatkowania, na wprowadzaniu zwolnien (podmiotowych lub przedmiotowych) i ulg lub obejmowaniu podatkami nowych podmiotów. Jednym $\mathrm{z}$ najważniejszych problemów, występujących w procesie jej realizacji jest właściwe kształtowanie 
dochodów podatkowych. Koncepcją teoretyczną, która wyjaśnia te kwestie to krzywa Laffera (Laffer, 1981).

Dyskrecjonalna polityka podatkowa jest skierowana zarówno na dochody konsumentów jak i inwestorów bądź też na ich aktywność gospodarczą. Jej wpływ na kształtowanie dochodów konsumentów, a tym samym ich popytu może następować przede wszystkim poprzez zmiany stawek podatków pośrednich (VAT, akcyza) na nabywane dobra konsumpcyjne. Czynnik ten w większości przypadków określa chęć lub zdolność kupna poszczególnych dóbr, a siła jego wpływu zależy przede wszystkim od krańcowej skłonności do konsumpcji: im skłonność ta będzie wyższa, tym wzrost stawki podatkowej będzie powodował słabszy spadek popytu na dobra konsumpcyjne.

Zgodnie ze stosowanymi zasadami stosowania polityki podatkowej w fazie niskiej aktywności gospodarczej powinno następować obniżenie stawek podatków pośrednich aby spowodować zahamowanie dynamiki spadku popytu na dobra konsumpcyjne, co może także doprowadzić do ograniczenia szybkości wzrostu bezrobocia koniunkturalnego i zmniejszenia dynamiki wzrostu zjawisk inflacyjnych. W okresie fazy wysokiej aktywności powinno następować zwiększenie stawek podatków pośrednich aby $\mathrm{w}$ ten sposób ograniczyć dynamikę wzrostu popytu na dobra konsumpcyjne (Krugman, Wells, 2012). Tego typu działanie, właściwe z punktu widzenia polityki stabilizacji, jest jednak bardzo trudne w praktycznej realizacji. Związane jest to z tym, że wzrost podatków pośrednich, a zwłaszcza akcyzy, może być czynnikiem przyspieszającym inflacyjny wzrost cen i nasilenie procesów wzrostu bezrobocia.

Organy państwa prowadzące politykę podatkową mogą również wpływać na popyt na dobra inwestycyjne. Najważniejszym instrumentem stosowanym w tym zakresie są premie inwestycyjne lub fundusze inwestycyjne (Teichmann, 1988). Ich wysokość i siła wpływu na popyt na dobra inwestycyjne zależy głównie od wysokości stawek podatków bezpośrednich (dochodowych). Rola podatków pośrednich jest mniejsza, a wzrost (spadek) stawek podatku VAT w okresie fazy wzrostowej (spadkowej) może doprowadzić do ograniczenia szybkości wzrostu (spadku) popytu na te dobra. Oznacza to, że ocena siły działania podatków pośrednich, skierowanych na zmiany popytu inwestycyjnego jest trudna. Wprowadzenie ulg lub zwolnień podatkowych $\mathrm{w}$ fazie niepomyślnej koniunktury, w warunkach pesymistycznych oczekiwań dotyczących możliwości sprzedaży, może jedynie doprowadzić do zamrożenia środków finansowych przedsiębiorstw, a nie do zwiększenia wydatków na działalność inwestycyjną. Wyższa skuteczność tego typu działań będzie występowała w fazie pomyślnej koniunktury. Zniesienie ulg inwestycyjnych, ograniczenie wysokości odpisów amortyzacyjnych czy też wzrost stawek podatków pośrednich może bowiem zmniejszyć rentowność podejmowanych inwestycji, co może ograniczyć szybkość wzrostu popytu na środki inwestycyjne.

Polityka podatkowa determinująca popyt na środki inwestycyjne może także być czynnikiem kształtującym sytuację na rynku pracy, gdyż wzrost nakładów inwestycyjnych może prowadzić do spadku bezrobocia ale jednocześnie może prowadzić do wzrostu inflacji (Blanchard, 2011).

Polityka wydatków budżetowych może również odgrywać stabilizującą rolę ze względu na to, iż powoduje zmiany popytu nie tylko na dobra konsumpcyjne ale i na środki inwestycyjne, przy czym związek ten jest wprost proporcjonalny, tj. wraz ze wzrostem wydatków budżetowych rośnie dochód narodowy (popyt efektywny). 
Wartość działającego mnożnika wydatków państwa zależy proporcjonalnie od krańcowej skłonności do konsumpcji (lub odwrotnie proporcjonalnie od krańcowej skłonności do oszczędzania), a w gospodarce otwartej jest dodatkowo, odwrotnie zależna od krańcowej skłonności do importu (Tichy, 1995).

Zmiany popytu konsumpcyjnego są determinowane przez wydatki osobowe lub socjalne, a także w części przez wydatki transferowane i mają one głównie charakter społeczny, a ponadto $\mathrm{w}$ stosunkowo niskim stopniu są determinowane zmianami poziomu aktywności gospodarczej. Płace i wynagrodzenia uzyskiwane ze środków budżetowych są w niskim stopniu zależne od stanu koniunktury, gdyż stawki płac dla tej grupy są wynikiem ustaleń taryfowych między pracodawcami i pracobiorcami. Wydatki budżetowe na cele socjalne wynoszą $\mathrm{w}$ niektórych krajach nawet $30 \%$ wytworzonego PKB, a zatem jest to ważny czynnik kształtujący popyt na dobra konsumpcyjne. Możliwość krótko- i średniookresowych zmian w tym zakresie jest bardzo ograniczona. W tym przypadku można jedynie sobie wyobrazić, że istnieją pewne możliwości wzrostu świadczeń socjalnych w warunkach niskiej aktywności gospodarczej, ale jedynie w stopniu na który pozwalają dochody budżetowe. Ograniczenie tych świadczeń w fazie pomyślnej koniunktury będzie praktycznie niemożliwe, głównie ze względów politycznych i społecznych.

Popyt na dobra inwestycyjne jest kształtowany przez tzw. rzeczowe wydatki oraz przez subwencje budżetowe. Wpływ ten jest istotny, gdyż w tym przypadku nie powstają oszczędności, które mogą modyfikować popyt inwestycyjny. Według zwolenników ekonomii keynesowskiej rzeczowe wydatki budżetowe, w wyniku których są podejmowane inwestycje, są najlepszym instrumentem wpływającym na stabilizowanie koniunktury, gdyż siła działania mechanizmów mnożnikowych jest stosunkowo wysoka. Ponieważ działanie mnożnika występuje w okresie niepełnego wykorzystania czynników produkcji, to wzrost wydatków budżetowych państwa w tym czasie może przyczyniać się do stopniowej poprawy koniunktury i do wychodzenia gospodarki z fazy niskiej aktywności. Wzrost krańcowej skłonności do konsumpcji może dodatkowo doprowadzić do wzrostu popytu konsumpcyjnego.

Zwiększenie wydatków budżetowych na konsumpcję lub inwestycje może powodować poprawę aktywności gospodarczej ale jednocześnie może przyczyniać się do zmniejszenia bezrobocia i nasilenia procesów inflacyjnych.

W grupie fiskalnych narzędzi polityki stabilizacji obok instrumentów działających dyskrecjonalnie występują także automatyczne stabilizatory koniunktury. Są to instrumenty, które działają w określonych warunkach gospodarczych, a których uruchomienie występuje zawsze wtedy, gdy następuje odchylenie głównych wielkości ekonomicznych od pożądanego poziomu. Ich wprowadzenie nie wymaga dodatkowych decyzji władz ustawodawczych czy wykonawczych, a ich efekty występują niezależnie od tego czy organy te uświadamiają sobie potrzebę ich stosowania czy też nie. W aspekcie instrumentalnym instrumenty te można zdefiniować jako środki służące nie tylko do utrzymywania w gospodarce równowagi na poziomie pełnego zatrudnienia lecz także są one wykorzystywane do sterowania równowagą między inflacją a bezrobociem tak aby działały one na rzecz kompensacji tendencji destabilizujących gospodarkę i prowadziły do powstawania warunków równowagi (Hansen, 1949).

Automatyczne stabilizatory koniunktury spełniając określone kryteria występują nie tylko w działaniach fiskalnych ale także w sferze pieniężnej lub też mogą wpływać 
na poziom i dynamikę konsumpcji (Kropiwnicki, 1976). Najważniejszą rolę stabilizacyjną pełnią one w systemie fiskalnym, gdyż występując po stronie dochodów i wydatków są stosowane zgodnie ze stałymi zasadami ich realizacji (PrzybylskaKapuścińska, 1984). Ich wykorzystanie wynika z wrażliwości niektórych podatków i wydatków państwa na zmiany ogólnej sytuacji gospodarczej.

Głównym zadaniem automatycznych stabilizatorów koniunktury jest oddziałanie na dynamikę popytu, a w szczególności hamowanie szybkości jego spadku lub ograniczenie dynamiki jego wzrostu. Cel ten jest osiagany przede wszystkim przez kształtowanie dochodów rozporządzalnych, przy czym w procesie stabilizacji popytu zdecydowanie większe efekty uzyskuje się oddziałując na rozmiary popytu konsumpcyjnego, zwłaszcza grup ludności, które odznaczają się wyższą skłonnością do konsumpcji. Konsekwencje wpływu tych narzędzi na dynamikę popytu na dobra inwestycyjne są zdecydowanie mniejsze (Hübner, Lubiński, 1988).

Do najczęściej wymienianych w literaturze środków polityki stabilizacji działających automatycznie, a które jednocześnie znalazły praktyczne zastosowanie należą stabilizatory $\mathrm{w}$ systemie podatków oraz w systemie ubezpieczeń społecznych (Kropiwnicki, 1976). W pierwszej grupie najważniejszą rolę odgrywają podatki bezpośrednie od dochodów indywidualnych lub od dochodów (zysków) korporacji, a także niektóre podatki pośrednie.

Podatki od dochodów indywidualnych są uważane za najważniejszy z automatycznych stabilizatorów, gdyż ich istotą jest to, że jeżeli nie występują zmiany stawek podatkowych i nie ulegają zmianie zasady zwolnień podatkowych, wówczas instrument ten powoduje wzrost stabilności wydatków konsumpcyjnych, pomimo zmian aktywności gospodarczej. W okresie niskiej aktywności dynamika dochodów podatkowych jest mniejsza aniżeli spadek PKB, co może prowadzić do powstania lub powiększania deficytu budżetowego. Z kolei w okresie wysokiej dynamiki wzrostu konsekwencje zmian podatków od dochodów osobistych są odwrotne, gdyż powodują one hamowanie wzrostu popytu konsumpcyjnego i zwiększenie dochodów podatkowych państwa. W tym okresie może pojawić się tendencja do powstawania nadwyżki lub zmniejszania deficytu budżetowego (Krugman, Wells, 2012).

Koniunkturalny wzrost wysokości dochodów budżetowych wskutek działania podatków dochodowych od osób fizycznych może być czynnikiem ograniczającym procesy inflacyjne, zwłaszcza w okresie wysokiej aktywności gospodarczej, co będzie powodowane zmniejszeniem podaży pieniądza gotówkowego na rynku. W niższym stopniu oddziałanie antyinflacyjne tych podatków można stwierdzić w fazie niskiej aktywności, gdy wskutek narzędzi automatycznych pojawią się tendencje do powiększania deficytu budżetowego i do wzrostu podaży gotówki na rynku. Pozytywny lub negatywny wpływ podatków dochodowych od osób fizycznych na nierównowagę na rynku pracy będzie słabszy.

Do grupy automatycznych stabilizatorów koniunktury należą także podatki od zysków korporacji, co jest powodowane ich dużą wrażliwością na zmiany aktywności gospodarczej. Jak wynika $\mathrm{z}$ analiz teoretycznych i empirycznych $\mathrm{w}$ okresie spadku koniunktury zyski korporacji spadają szybciej aniżeli PKB, a zatem w warunkach niezmiennej presji podatkowej zmniejszają się także dochody budżetowe z podatku obciążającego te zyski. W czasie fazy pomyślnej koniunktury dynamika zysków jest wyższa aniżeli innych dochodów, co powoduje, że dochody podatkowe rosną szybciej 
aniżeli PKB. Presja podatkowa hamuje więc spadek zysków netto korporacji w fazie niskiej aktywności, natomiast $\mathrm{w}$ okresie fazy wzrostowej ogranicza dynamikę ich wzrostu. Zyski netto korporacji podlegają podziałowi na zyski niepodzielne (oszczędności) oraz zyski podzielone (dywidendy). Oznacza to, że podatki te mogą przyczynić się do poprawy sytuacji na rynku pracy (wzrost zatrudnienia), gdyż w wyniku ich działania mogą powstawać nowe miejsca pracy.

Podatki pośrednie mogą działać w sposób automatyczny w grupie podatków akcyzowych, nakładanych na dobra konsumpcyjne. Oznacza to, że kształtują one dochody realne ludności o najniższych dochodach. Dochody podatkowe z tytułu akcyzy najczęściej rosną $\mathrm{w}$ okresie pomyślnej koniunktury, natomiast maleją $\mathrm{w}$ fazie niepomyślnej koniunktury. Powoduje to zmniejszenie szybkości spadku popytu konsumpcyjnego $\mathrm{w}$ fazie spadkowej oraz hamowanie jego wzrostu $\mathrm{w}$ fazie wysokiej aktywności. Wzrost (spadek) obciażeń podatkiem akcyzowym może być czynnikiem pobudzającym (hamującym) procesy inflacyjne, zwłaszcza w okresie fazy wzrostowej (spadkowej) cyklu koniunkturalnego, co może doprowadzić do pogorszenia (poprawy) sytuacji na rynku pracy.

Druga grupa automatycznych stabilizatorów koniunktury działa po stronie wydatkowej budżetu, głównie w systemie ubezpieczeń społecznych. Elementami składowymi działającymi automatycznie jest przede wszystkim system kompensacji skutków bezrobocia oraz ubezpieczenia na starość lub przeżycie (Kropiwnicki, 1976). W przypadku gdy w gospodarce występuje faza niepomyślnej koniunktury, gdy rośnie liczba osób pozostających bez pracy, zwiększa się liczba osób korzystających z systemu zabezpieczeń społecznych i zwiększają się wypłaty zasiłków, a tym samym hamowany jest spadek popytu na dobra konsumpcyjne.

Z przeprowadzonych rozważań wynika, że działające automatyczne stabilizatory fiskalne mogą i powinny być wykorzystywane $\mathrm{w}$ procesie stabilizacji makroekonomicznej. Działania te w najwyższym stopniu i w bezpośredni sposób mogą się przyczyniać do poprawy wyniku budżetu państwa. Wprawdzie cel ten nie jest powszechnie formułowany $\mathrm{w}$ literaturze, gdyż jego realizacja jest $\mathrm{w}$ zasadzie sposobem osiagania szybkiego wzrostu gospodarczego, poprawy sytuacji na rynku pracy czy też ograniczania zjawisk inflacyjnych. Stosowane narzędzia fiskalne mogą być także czynnikiem łagodzącym amplitudę wahań koniunkturalnych, zwłaszcza na rynku dóbr konsumpcyjnych, co powinno przyczyniać się do przyspieszenia wzrostu w warunkach równowagi. Automatyczne narzędzia fiskalne mogą także w istotny sposób ograniczać negatywne skutki bezrobocia. Nie będą one w bezpośredni sposób likwidować jego przyczyn ale mogą przyczyniać się do hamowania szybkości spadku popytu konsumpcyjnego. W procesie zmniejszania inflacji główną rolę odgrywają wprawdzie narzędzia polityki pieniężnej, to jednak np. zmniejszenie deficytu budżetowego lub ograniczenie stawek podatku akcyzowego mogą $\mathrm{W}$ istotnym stopniu powodować hamowanie dynamiki wzrostu cen.

\section{Podsumowanie}

Narzędzia polityki fiskalnej mogą i powinny być współcześnie wykorzystywane w działaniach stabilizacyjnych. Szczególnie istotną rolę mogą one odgrywać w procesie kształtowania morfologii cykli koniunkturalnych i sytuacji na rynku pracy. Ich znaczenie 
w hamowaniu procesów inflacyjnych jest mniejsze co może być spowodowane tym, że obecnie w polityce antyinflacyjnej dominują narzędzia polityki pieniężnej.

Wśród narzędzi fiskalnych można wyróżnić instrumenty dyskrecjonalne jak i działające automatycznie. W pierwszej grupie główną rolę odgrywają podatki pośrednie (VAT, akcyza) oraz wydatki budżetowe, głównie na cele inwestycyjne. Wśród narzędzi działających automatycznie dominuja podatki dochodowe od osób prawnych i od osób fizycznych oraz zasiłki dla bezrobotnych.

Działania stabilizacyjne narzędzi fiskalnych mogą powodować deformację morfologii współczesnych cykli koniunkturalnych (skrócenie długości i zmniejszeniem ich amplitudy), ograniczenie nierównowagi podażowej na rynku pracy (zmniejszenie bezrobocia) oraz hamowania dynamiki procesów inflacyjnych. Te pozytywne skutki są w wyższym stopniu konsekwencją działania automatycznych stabilizatorów koniunktury, natomiast efekty narzędzi dyskrecjonalnych są w tym zakresie relatywnie mniejsze. Wynika to głównie $\mathrm{z}$ wyższej ich sztywności, związanej z występującymi opóźnieniami czasowymi.

W tych warunkach ważnym problemem poznawczym, wyjaśniającym, a tym samym praktycznym jest empiryczna analiza znaczenia i charakteru wpływu narzędzi polityki fiskalnej, prowadzona w różnych gospodarkach rynkowych, a w szczególności w krajach w których występują nie tylko działania stabilizacyjne ale także przemiany strukturalne. Do grup takich systemów z całą pewnością należy Polska.

\section{Literatura}

Barczyk R., 2004: Teoria i praktyka polityki antycyklicznej, AE, Poznań, s.16.

Blanchard O., 2011: Makroekonomia, Oficyna Wolters Kluwer, Warszawa, s. 849.

Cassel D., Thieme H.J., 1997: Einkommenspolitik Kritische. Analyse eines umstrittenem stabilitätspolitischen Konzepts, Kiepenheuer and Witsch, Köln, s. 96.

Despres E., Friedman M., Hart A.G., Samuelson S.A., Wallace D.W., 1975: Problem niestabilności gospodarczej, w: Teoria i polityka stabilizacji koniunktury. Wybór tekstów, PWN, Warszawa, s. 41-42.

Hansen A.H., 1949: Economic Policy and Full Employment, New York, s. 248-249.

Hübner D., Lubiński M., 1988: Współczesny cykl koniunkturalny, Warszawa, s. 192-193.

Kołodko G.W., 1993: Kwadratura pięciokąta. Od załamania gospodarczego do trwałego wzrostu, Poltex, Warszawa, s.46.

Kropiwnicki J., 1976: Teoria automatycznych stabilizatorów koniunktury, Warszawa, s. 143.

Krugman P., Wells R., 2012: Makroekoonmia, Wyd. Naukowe PWN Warszawa, s. 357-361, 372-377.

Laffer A., 1981: The New Economics. A Debate „Economic Impact”, No 3.

Mussel G., Pätzold J., 2012: Grundfragen der Wirtschaftspolitik, 8-th ed. Vahlen, München, s. 22. Nasiłowski M., 1996: System rynkowy. Problemy mikro- i makroekonomii, Warszawa, s. 209.

Owsiak S., 2017: Finanse publiczne. Współczesne ujęcie, PWN, Warszawa, s. 489-490.

Pätzold J., 1991: Stabilisierungspolitik. Grundlagen der nachfrage- und angebotsorientierten Wirtschaftspolitik, Vahlen Vertag, Bonn-Stuttgart, s. 38-40.

Przybylska-Kapuścińska W., 1984: Automatyczne i dyskrecjonalne stabilizatory koniunktury gospodarczej w systemie fiskalnym, w: Interwencjonizm państwowy. Zagadnienia wybrane, AE, Poznań, s. 112.

Teichmann U., 1988: Grundriß der Konjunkturpolitik, München.

Tichy G.J., 1995: Konjunkturpolitik. Quantitative Stabilisierungspolitik bei Unsicherheit, Springer Verlag. 


\begin{abstract}
By means of fiscal and/or monetary instruments, highly developed market economies undertake stabilization activities which aim (among other things) to influence the morphology of business cycles and the equilibrium of the labor market, as well as striving to maintain a stable value of currency. The aim of the article is to examine the hypothetical impact of both discretionary and automatic fiscal policy tools on stabilization of the real and the nominal sphere of a closed market economy. The article is hypothetical in nature. First, the aims of macroeconomic stabilization and the possibilities of their implementation are discussed. Later, discretional and automatic fiscal instruments are presented, and the nature of their impact upon accomplishment of the previously formulated goals is examined. Fiscal instruments can and should be used in stabilization activities and the tools that operate automatically should be particularly important for policy makers.
\end{abstract}

Key words: macroeconomic stabilization, fiscal discretional and automatic instruments, cyclical fluctuations, unemployment, inflation.

JEL Codes: E62,E32.

Informacje o autorze:

Ryszard Barczyk, prof. dr hab.

Katedra Koniunktury Gospodarczej

Uniwersytet Ekonomiczny w Poznaniu

al. Niepodległości 10, Poznań, Polska

e-mail: ryszard.barczyk@ue.poznan.pl

ORCID: 0000-0002-9875-4403 